\title{
Macroalgal grazing selectivity among herbivorous coral reef fishes
}

\author{
Chrystal S. Mantyka, David R. Bellwood* \\ School of Marine and Tropical Biology, and Australian Research Council Centre of Excellence for Coral Reef Studies, \\ James Cook University, Townsville, Queensland, 4811, Australia
}

\begin{abstract}
Despite growing interest in examining functional groups among coral reef species, few studies have examined the relative functional impacts of individual herbivorous fish species in coral reef ecosystem processes. We investigated potential functional roles within an herbivorous reef fish assemblage by assessing the feeding selectivity of fishes on macroalgae. Transplanted multiplechoice algal assays and remote stationary underwater digital video cameras were used to quantify the feeding selectivity of 6 herbivorous reef fish species: Siganus doliatus and S. canaliculatus (Siganidae); Chlorurus microrhinos, Hipposcarus longiceps, and Scarus rivulatus (Labridae); and Pomacanthus sexstriatus (Pomacanthidae). The siganids strongly selected Sargassum sp. (Phaeophyta) and, to a lesser extent, Hypnea sp. (Rhodophyta), but strongly avoided calcified macroalgae. However, S. doliatus displayed strong selection for Hypnea sp., whereas S. canaliculatus exhibited stronger selection for Sargassum sp. In contrast, the parrotfishes exhibited similar selectivities, with all 3 species selecting heavily calcified Halimeda spp. (Chlorophyta), but strongly avoiding Galaxaura sp. (Rhodophyta) and other red and brown macroalgal species. The pomacanthid was the least selective of the 6 fish species, exhibiting no clear selection or avoidance. These results emphasize the potential variation among species within presumed functional groups, and the need for care when defining functional groups at the family or the genus level. The extent of specialization, with strong selection and avoidance, suggests that functional redundancy among herbivores may be less than previously assumed.
\end{abstract}

KEY WORDS: Selectivity $\cdot$ Herbivorous coral reef fishes $\cdot$ Functional roles $\cdot$ Redundancy $\cdot$ Remote underwater video

\section{INTRODUCTION}

Functional groups are unified by a shared ecological role irrespective of their taxonomic affinities (Steneck 2001). A number of functional groups have been described within the marine herbivore category on coral reefs (e.g. grazers, macroalgal browsers, and detritivores; see e.g. Wilson et al. 2003, Choat et al. 2004, Mumby et al. 2006). Such functional groups have provided a useful basis for considering the role and importance of herbivorous reef fishes in maintaining coral reef resilience and avoiding coral-algal phaseshifts (Hughes et al. 2003, 2007, Bellwood et al. 2004, 2006, Mumby et al. 2006). However, little is known of the functional groups that regulate this transition from coral to macroalgal dominance, particularly in the Indo-Pacific. For example, which species eat macroalgae on inshore reefs, where macroalgae are most abundant?

A critical component in understanding this coralalgal transition is knowledge of selectivity among herbivorous reef fishes for macroalgal species. For example, herbivorous reef fish species within a functional group may be considered functionally redundant if the species in that group exhibit the same feeding selectivity. However, it is not known to what extent reef fish species exhibit selection and/or avoidance. If similar herbivorous reef fish species exhibit markedly different feeding selectivity, they may no longer be functionally redundant. The loss of one species may therefore 
have a disproportionately large effect on the diversity and community composition of algae on reefs. We examined the potential of coral reefs to cope with change by evaluating the extent to which resident herbivores will prey on macroalgae.

Several factors have been examined as potential determinants of food selectivity and preferential feeding in herbivorous fishes. These factors include: algal nutritional characteristics (e.g. Pillans et al. 2004, Raubenheimer et al. 2005), spatial and temporal variation in algal availability (e.g. Pillans et al. 2004), algal defenses in the form of chemical and/or morphological traits, such as secondary metabolites, toughness, and calcification (e.g. Paul \& Hay 1986, Targett \& Targett 1990, Duffy \& Paul 1992, Meyer et al. 1994), digestive capabilities of fish (e.g. Clements \& Choat 1997), and oral jaw biomechanics (e.g. Bellwood \& Choat 1990, Purcell \& Bellwood 1993).

In studies of food selectivity of herbivorous fishes, the most frequently used technique for determining the degree of food selectivity is gut content analysis (e.g. Randall 1967, Ojeda \& Muñoz 1999, Raubenheimer et al. 2005). Gut content analyses are advantageous in that one can identify selection from a wide range of natural prey. However, the presence and abundance of an algal species in the gut may be related to algal availability in the field, rather than selection. In this, it reflects the realized niche rather than the potential niche. Alternative techniques used in examining food selectivity in herbivorous fishes include direct observations (Lewis 1985, Bruggemann et al. 1994), inference from caging experiments (Ceccarelli et al. 2006), aquarium-based feeding experiments (Targett \& Targett 1990, Ojeda \& Muñoz 1999), and video observations (Bellwood et al. 2006). Each technique addresses different aspects of selectivity. Direct observations provide valuable information on the natural diet of fishes in the field, but the fishes are restricted to available resources, and the presence of the observer may have significant effects on the fish's natural feeding behavior (Bellwood et al. 2006). Caging experiments may reflect selectivity at the family or system level, but cannot identify the feeding selectivity of individual consumers. Aquarium-based feeding experiments allow for isolation of specific individual herbivorous fish species in the laboratory, but the extent to which they reflect 'natural' patterns may be questionable (e.g. Ojeda \& Muñoz 1999). Video observations, where remote stationary underwater digital video cameras are used to film feeding selectivity, provide a compromise in that they offer a means to record the feeding selectivity of herbivorous fishes in the field, on natural or modified substrata, without the presence of an observer. They provide a direct evaluation of potential functional roles. In the past, similar designs without the use of video cameras have been used to offer specific food items on natural or modified substrata to detect algal deterrence (e.g. Paul \& Hay 1986). However, the use of cameras enables the fish species exhibiting this selectivity to be identified.

The central goal in the present study was to evaluate the potential niche of herbivorous fishes. This reflects their capacity to cope with change. One of the most widely reported changes on coral reefs is a marked increase in macroalgal cover (e.g. Mumby et al. 2006, Hughes et al. 2007). If macroalgae become widespread, which fish species would be able and motivated to feed on various macroalgal species? The specific aim of this study, therefore, was to assess the feeding selectivity of 6 reef fish species: Siganus canaliculatus and $S$. doliatus (Siganidae); Chlorurus microrhinos, Hipposcarus longiceps, and Scarus rivulatus (parrotfishes, Labridae; Westneat et al. 2005); and Pomacanthus sexstriatus (Pomacanthidae), using video observations and transplanted multiple-choice algal assays. These 6 species are functionally the most important herbivorous reef fish species at the study site and are among the most abundant herbivorous fishes on Great Barrier Reef (GBR) inshore reefs (Fox \& Bellwood 2007, Mantyka \& Bellwood 2007).

\section{MATERIALS AND METHODS}

Study site and macroalgae. The study was conducted between February and March 2006 in Pioneer Bay on the leeward side of Orpheus Island $\left(18^{\circ} 35^{\prime} \mathrm{S}\right.$, $146^{\circ} 20^{\prime} \mathrm{E}$ ) on the inner shelf of the GBR, Australia. Two fringing reef crest sites located at the northern end of the bay were selected. Both study sites are protected from commercial and recreational fishing and have relatively low levels of macroalgal cover (Fox \& Bellwood 2007). Twelve species of macroalgae were examined, of which 8 were collected along the inner and mid-intertidal reef flat of Pioneer Bay (Chlorophyta: Halimeda cylindracea, $H$. discoidea, and H. opuntia; Rhodophyta: Amphiroa sp. and Laurencia sp. 2; and Phaeophyta: Padina sp., Sargassum sp., and Turbinaria ornata). Galaxaura sp. (Rhodophyta) was collected from the outer reef flat and crest, Chlorodesmis fastigiata (Chlorophyta) from the reef crest, and Laurencia sp. 1 and Hypnea sp. (Rhodophyta) from a buoyed mooring line, approximately $25 \mathrm{~m}$ from the reef crest. The macroalgal species selected for this study were chosen to represent all 3 divisions of macroalgae (Chlorophyta, Rhodophyta, and Phaeophyta) and display a wide range of morphologies, and they were locally abundant. Padina sp., Sargassum sp., and Galaxaura sp. were particularly abundant on the adjacent reef flat. Macroalgal species 
were removed, ensuring that the holdfast was intact where possible, and transferred to outdoor recirculating seawater tanks until they were used in the feeding trials (within $24 \mathrm{~h}$ of collection). Macroalgae were identified to species where possible, but in most cases were only identified to genus because of the difficulty in identifying macroalgae to species level in the field, especially rhodophytes. Algal taxonomy in the IndoPacific is not well resolved, and unfortunately, significant taxonomic challenges remain. However, Galaxaura sp. closely resembled G. rugosa, and Laurencia sp. 1 resembled $L$. filiformis.

Macroalgal selectivity trials. Selection differs from preference in that 'macroalgal selection' is the process by which an individual chooses an alga, whereas 'macroalgal preference' is the likelihood that an alga will be selected if offered on an equal basis with others (Manly et al. 2002). In the present study, the macroalgal selectivity of the 6 herbivorous reef fishes was measured through cafeteria-style selectivity trials using multiple-choice algal assays. These assays differed from feeding preference experiments in that each assay contained 1 'proportional-sized' specimen of each of the 12 macroalgal species to reflect their usual growth form (rather than 'equal-sized' specimens as required for measures of preference). The average masses of the macroalgal species used in the assays were $1.1 \mathrm{~g}$ (Chlorodesmis fastigiata), $6.8 \mathrm{~g}$ (Turbinaria ornata), $8.0 \mathrm{~g}$ (Halimeda discoidea), $10.3 \mathrm{~g}$ (Laurencia sp. 2), 13.8 g (Hypnea sp.), 14.0 g (Padina sp.), $14.1 \mathrm{~g}$ (H. cylindracea), $19.5 \mathrm{~g}$ (Laurencia sp. 1), 22.9 g (Amphiroa sp.), $29.3 \mathrm{~g}$ (H. opuntia), $45.7 \mathrm{~g}$ (Sargassum sp.), and $62.6 \mathrm{~g}$ (Galaxaura sp.). Selectivity herein differed from ecological selectivity in that it did not directly examine selection versus natural availability. Each specimen was tied in random order onto a $1 \mathrm{~m}$ long piece of fishing line at approximately $8 \mathrm{~cm}$ intervals. Damaged or discolored algae were not used in the assays. The algae were transported in plastic selfsealed bags and deployed on the crest of each site using SCUBA. New sites were selected for each deployment. Algae were secured by tying the end of the fishing line to the reef. A stationary underwater digital video camera was placed on a tripod approximately 1 to $2 \mathrm{~m}$ from the multiple-choice algal assays to record the feeding activity of the herbivorous reef fishes.

Macroalgal selectivity trials commenced at 08:00 and at 13:00 h, over $7 \mathrm{~d}$. Feeding activity was recorded for 3 consecutive hours with obligatory tape and battery changes at 09:30 and 14:30 h. In total, 28 filmed selectivity trials $(84 \mathrm{~h})$ were recorded, 14 at each site (7 morning, 7 afternoon).

Quantification of selectivity. Food selectivity of the 6 herbivorous reef fish species was quantified by recording the total number of bites taken by each fish species on each macroalgal species, for the entire $3 \mathrm{~h}$ feeding trial (total $84 \mathrm{~h}$ ). Observations were divided into $5 \mathrm{~min}$ intervals to permit further subdivision if necessary. All observations were restricted to adult fishes: Siganus doliatus $>15 \mathrm{~cm}, S$. canaliculatus $>25 \mathrm{~cm}$, Chlorurus microrhinos $>30 \mathrm{~cm}$, Hipposcarus longiceps $>25 \mathrm{~cm}$, Scarus rivulatus $>25 \mathrm{~cm}$, and Pomacanthus sexstriatus $>30 \mathrm{~cm}$, and only included those trials in which all 6 study fish species were present. During the selectivity trials, no agonistic interactions were observed between any of the 6 study species (or any other species in the vicinity), nor did the fishes reach such high abundances that access to the full range of algae was reduced. It appeared that each fish species was able to express selectivity without impact from the other species. For each of the 6 fish species, the number of times each alga was selected first in selectivity trials ('first bites') was also recorded to test for selection based on vision and/or olfaction (i.e. before consumption). A note was made of the time taken for macroalgal species to be physically reduced by herbivory to a size that could not be visually identified/detected on the video footage.

Statistical analyses. The macroalgal selection could not be analyzed with an ANOVA because each algal specimen within each selectivity trial was not independent (i.e. the selection of one algal species may be dependent on the presence of other algal species in a trial). Selection by each of the 6 herbivorous reef fish species was therefore analyzed using 2 separate techniques: Friedman's test and Strauss' Linear Selection Index. In the first method, the mean number of bites per macroalgal species was compared and analyzed with a non-parametric Friedman test, followed by Friedman a posteriori multiple comparison tests (Conover 1999). In the second method, selection was measured based on a selectivity index, Strauss' Linear Selection Index $(L): L=r_{i}-p_{i}$, where $r_{i}$ is the number of bites from macroalga $i$, as a percentage of the total number of bites from all macroalgae during each feeding trial, and $p_{i}$ is the percentage of the total algal mass presented at the beginning of every feeding trial belonging to macroalga $i$. Selectivity indices for each macroalgal species were averaged over all feeding trials for each of the 6 herbivorous reef fish species, and $95 \%$ confidence intervals (CI) were calculated. CI values above 0.0 indicate selection, values less than 0.0 indicate avoidance, and CI values that encompass 0.0 indicate that selection of the macroalga did not differ significantly from random. These 2 methods were chosen to represent different approaches used throughout the literature. Thus, if both techniques produce similar results, one can be more confident that the results are likely to provide an accurate representation of algal selectivity by the 6 fish species. 


\section{RESULTS}

The total number of bites taken from macroalgae by the 6 herbivorous reef fish species during the first hour of feeding $(85 \%)$ was more than 5 times greater than the second $(13 \%)$ and third hours $(2 \%)$ combined. Although macroalgal species varied significantly in the time taken to reach the point where they were too small to be detected on the video footage (Friedman test, $\chi_{2}=115.55, \mathrm{p}<0.001$; Fig. 1), all macroalgal species were present throughout the first hour of feeding trials, with the sole exception of Laurencia sp. 2 (lost on average after $35 \mathrm{~min}$, Fig. 1). Given that almost all macroalgae were present during most of the first hour of feeding trials, and that the vast majority of bites occurred during this period, all subsequent analyses were restricted to the first hour of data when the full range of macroalgae were available to best evaluate selectivity.

Siganus doliatus and $S$. canaliculatus displayed strong feeding selectivity. In $S$. doliatus, the number of bites taken from Sargassum sp. and Hypnea sp. was significantly greater ( $60 \%$ of all bites) than from any other algal species (Friedman test, $\chi_{2}=42.945, \mathrm{p}<$ 0.001; Fig. 2a). Strauss' Linear Selection Index indicated that $S$. doliatus selected Sargassum sp., Hypnea sp., Laurencia sp. 2, and Turbinaria ornata (Fig. 2b), and avoided 6 of the remaining 8 algal species. In comparison, S. canaliculatus took a significantly larger number of bites from Sargassum sp. (60\% of all bites) than from any other macroalgal species (Friedman test, $\chi_{2}=171.938, p<0.001$; Fig. 2a). Strauss' Linear Selec-

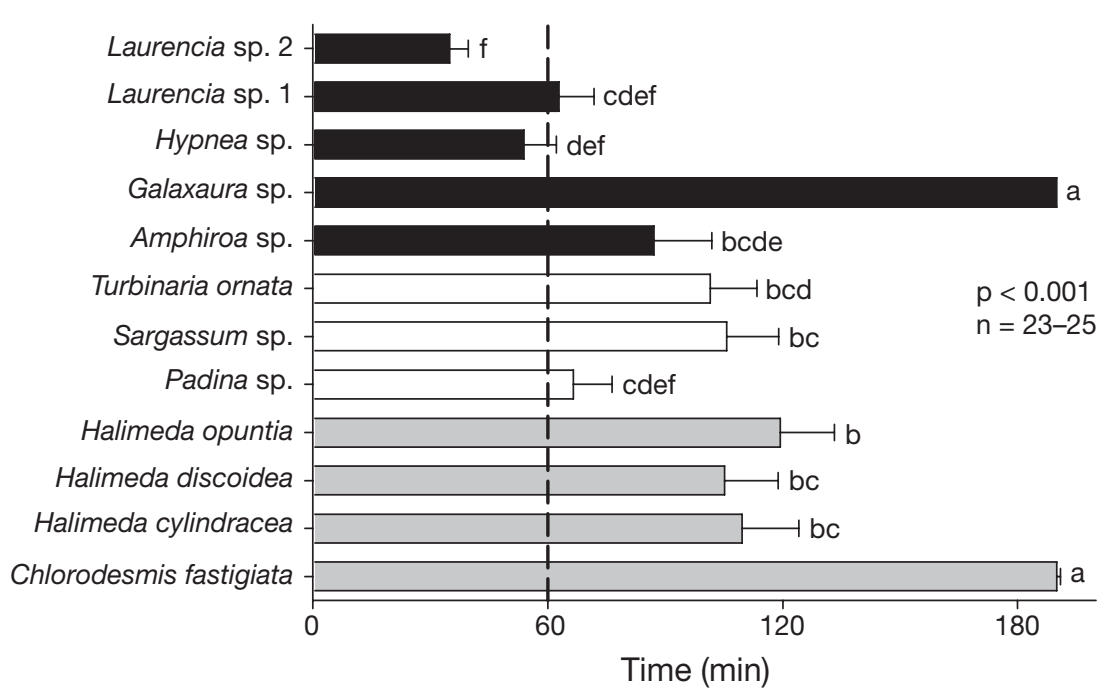

Fig. 1. Time required for macroalgae to be reduced to a size that could not be visually identified/detected on video footage. Bars represent means \pm SE. Analysis was by Friedman's test followed by Friedman's multiple comparisons test. Letters indicate homogenous subgroups, $\mathrm{n}=23$ to 25 for each species.

Black bars: Rhodophyta; open bars: Phaeophyta; grey bars: Chlorophyta tion Index indicated that $S$. canaliculatus selected Sargassum sp. and Padina sp., and avoided the green macroalgae (Halimeda opuntia, H. cylindracea, H. discoidea, and Chlorodesmis fastigiata), Galaxaura sp. and Amphiroa sp. (Fig. 2b). Thus, based on both techniques, $S$. doliatus consistently selected Sargassum sp., Hypnea sp., Laurencia sp. 2 and, to a lesser extent, T. ornata. In contrast, $S$. canaliculatus consistently selected Sargassum sp. and, to a lesser extent, Padina sp. over all other macroalgal species. Both fish species avoided the green macroalgal species and the red Galaxaura sp. and Amphiroa sp.

In contrast to the siganids, the parrotfishes Hipposcarus longiceps, Chlorurus microrhinos, and Scarus rivulatus all significantly avoided Sargassum sp., but exhibited selection for Halimeda opuntia (Friedman tests: Hipposcarus longiceps, $\chi_{2}=75.439, \mathrm{p}<0.001 ; C$. microrhinos, $\chi_{2}=121.005, \mathrm{p}<0.001 ;$ S. rivulatus, $\chi_{2}=$ 89.798, p < 0.001; Fig. 2c,d). The most interesting result from Strauss' Linear Selection Index was that all 3 parrotfish species consistently selected 1 or more species of Halimeda $(H$. opuntia, $H$. cylindracea, or $H$. discoidea; Fig. 2d). Furthermore, all 3 species consistently avoided Galaxaura sp., and, to a lesser extent Hypnea sp., Laurencia sp. 1, Laurencia sp. 2, Sargassum sp., Padina sp., and Turbinaria ornata.

Pomacanthus sexstriatus exhibited the least selectivity. The Friedman test indicated a significantly higher bite rate on the red macroalga Hypnea sp. compared to that of any of the brown or green macroalgae, but it was not significantly different from either of the Laurencia species $\left(\chi_{2}=65.922, \mathrm{p}<0.001\right.$; Fig. 2a). Strauss' Linear Selection Index also showed selection for Hypnea sp., but avoidance for the green and brown macroalgae (Fig. 2b). However, these relationships were not as distinct as those in either the siganid or parrotfish species.

When 'first bites' were compared to the total number of bites per alga, there was a general relationship between the 2 variables for each of the 6 dominant herbivorous reef fish species (Fig. 3). As 'first bites' increased for a particular macroalgal species, the total number of bites for that macroalgal species also increased. Overall, the 6 herbivorous reef fish species did not appear to be selecting macroalgae at random, but rather they appeared to target specific macroalgal species from the beginning of every selectivity trial and then continued to feed on those algae until they were no longer available. 

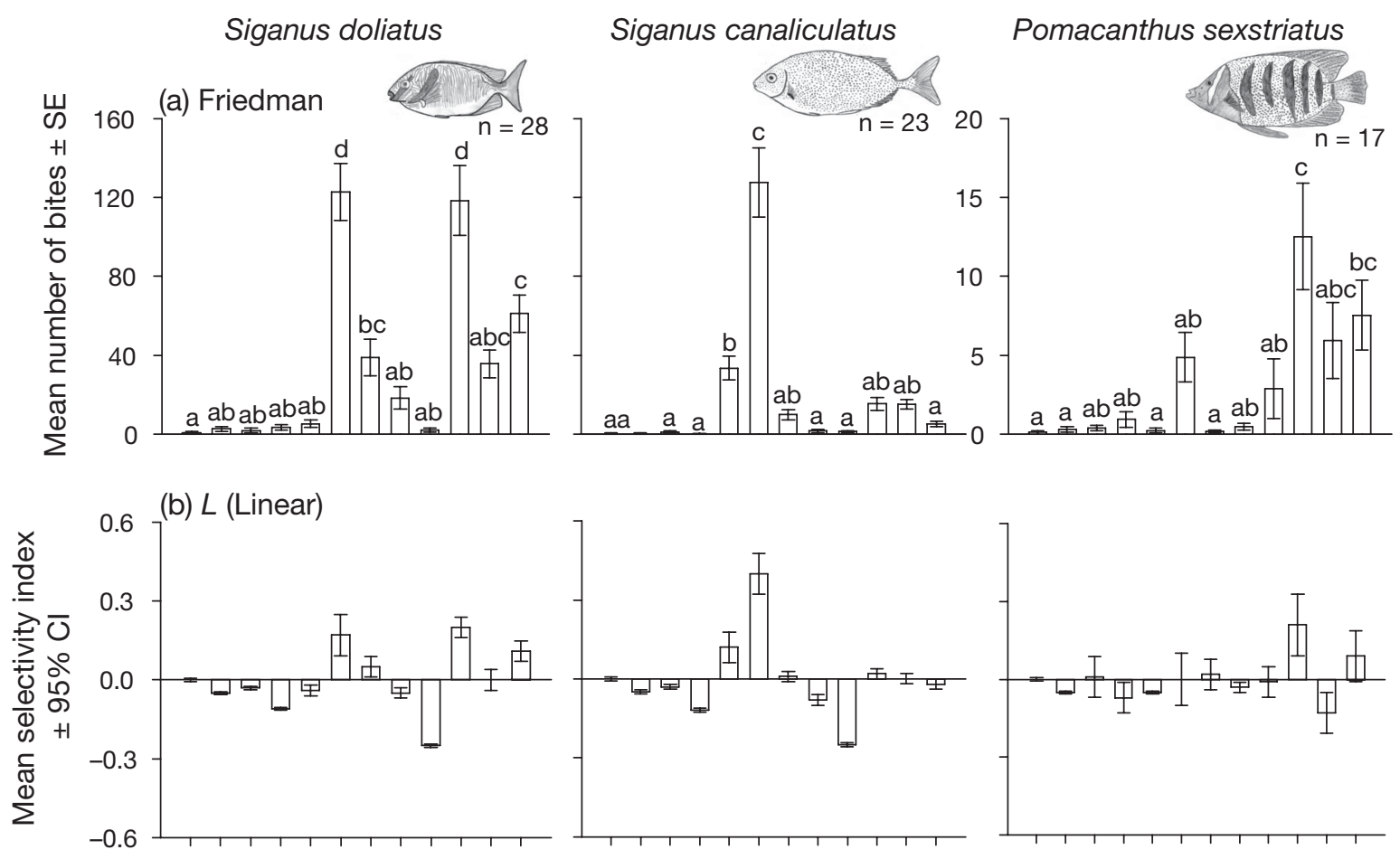

Hipposcarus longiceps

Chlorurus microrhinos

Scarus rivulatus
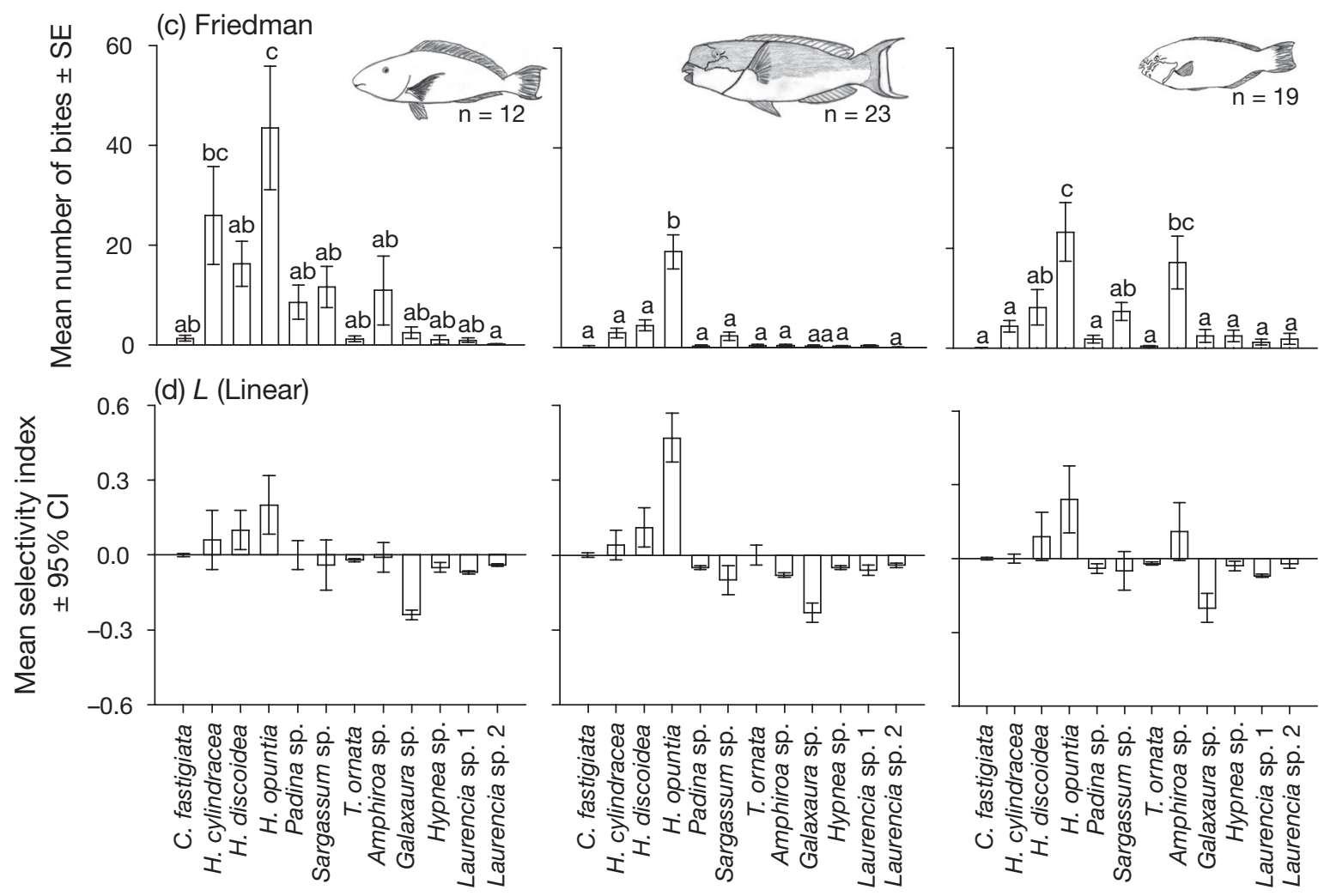

Fig. 2. Feeding selectivity by 6 herbivorous reef fish species. (a,b) Siganus doliatus, S. canaliculatus, and Pomacanthus sexstriatus; (c,d) Hipposcarus longiceps, Chlorurus microrhinos, and Scarus rivulatus. (a,c) Mean number of bites per algal species, analyzed using Friedman's test followed by Friedman's multiple comparisons tests; letters indicate homogenous subgroups. (b,d) Mean selectivity estimated using Strauss' Linear Selection Index $(L)$. Full algal species names given in Fig. 1 

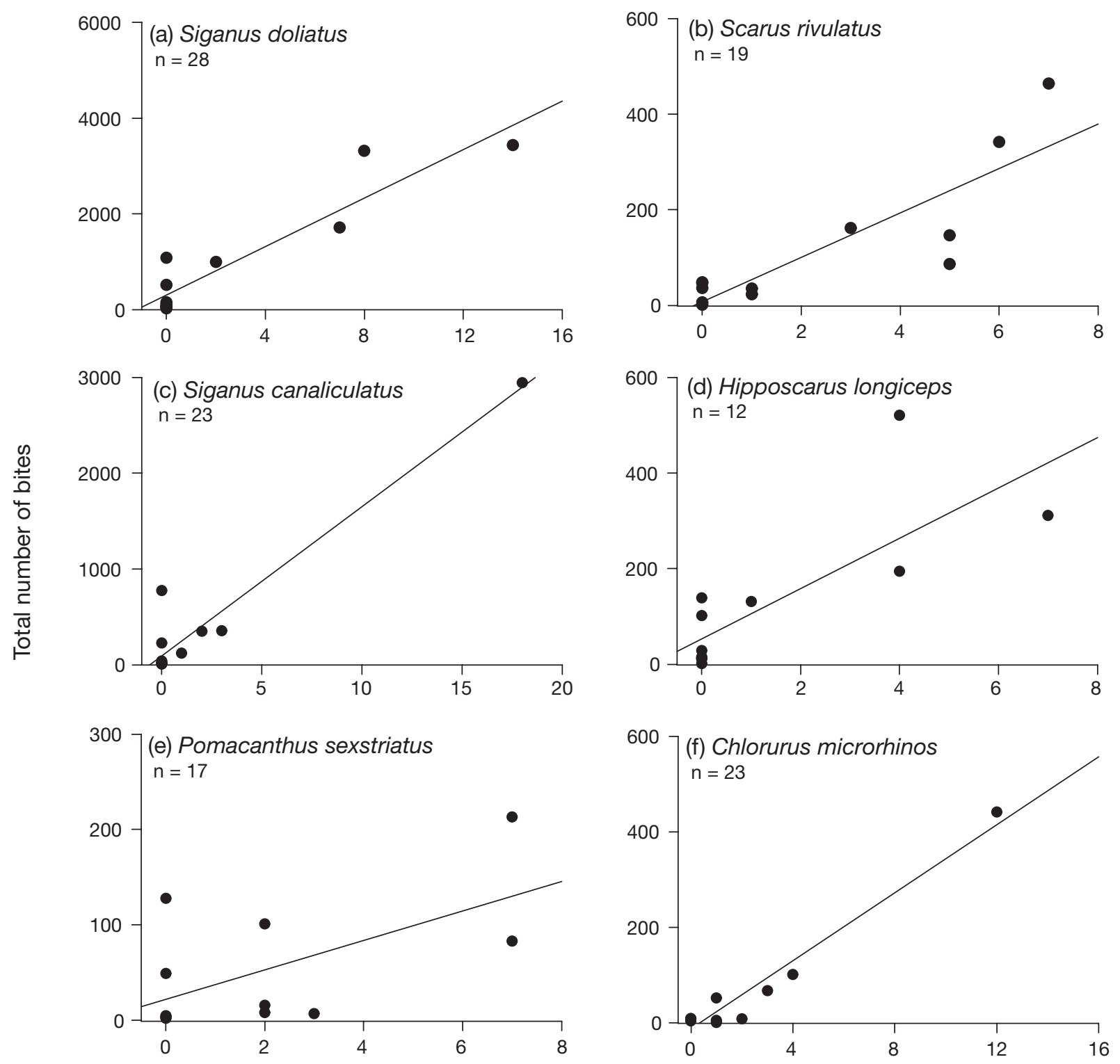

Total number of first bites

Fig. 3. Relationship between the total number of first bites on each alga versus the total number of bites taken from that alga by 6 herbivorous reef fish species, over all selectivity trials. Each data point represents a separate macroalgal species. Lines represent trend lines

\section{DISCUSSION}

The herbivorous reef fishes in Pioneer Bay exhibited considerable selectivity in their feeding, with the extent and nature of selectivity varying within and among families. Siganus doliatus selected Hypnea sp., Laurencia sp. 2, and Sargassum sp., while S. canaliculatus selected Sargassum sp. and Padina sp. Both siganids avoided the green macroalgae and the red Galaxaura sp. and Amphiroa sp. No previous food selection studies have examined either of these 2 siganid species on the GBR. However, previous studies of selectivity in siganids have reported strong selectivity. For example, using multiple-choice assays in the laboratory, Pillans et al. (2004) observed that S. fuscescens (a close relative of $S$. canaliculatus) from Southern Queensland (Australia) preferred red algae (Acanthophora spicifera and Gracilaria edulis) over brown algae (Dictyota dichotoma and Lobophoroa variegata). Using a combination of direct observations in the lab and gut content analyses in the field in the Philippines, Von Westernhagen $(1973,1974)$ likewise 
found that $S$. concatenata (synonym of $S$. guttatus), $S$. oramin (synonym of $S$. canaliculatus), S. striolata (synonym of $S$. spinus), and $S$. virgata (synonym of $S$. virgatus) selected various fleshy green and red macroalgae of the genera Enteromorpha, Gracilaria, Hypnea, and Laurencia, and ignored brown and calcareous algae. Furthermore, Tsuda \& Bryan (1973) used feeding preference experiments in outdoor tanks on Guam and reported that Chlorodesmis fastigiata was avoided by juvenile $S$. spinus but was readily consumed by juvenile $S$. argenteus (see also Paul et al. 1990).

Given this level of selectivity, the extent of functional redundancy and the potential for the replacement of Siganus doliatus and $S$. canaliculatus by other functional groups in Pioneer Bay may be limited. Of the 33 roving herbivores recorded from the bay, only 2 others have been reported to feed on Sargassum to any significant extent: Scarus rivulatus and Platax pinnatus (Bellwood et al. 2006). The latter was the dominant browser of large macroalgal strands, but was not observed feeding on macroalgae in the selectivity trials in the present study. Thus, it could be argued that this system currently displays limited functional redundancy in terms of feeding on Sargassum spp. and that $S$. doliatus and $S$. canaliculatus represent important species to conserve locally for the maintenance of low Sargassum cover on inshore reefs.

Macroalgal selectivity by parrotfishes differed greatly from the siganids in that the parrotfishes consistently selected 1 or more of the green heavily calcified Halimeda species, while avoiding the brown macroalgae, including Sargassum sp. and the majority of the red macroalgae, especially Galaxaura sp. The relatively uniform selectivity of these 3 parrotfish species suggests that this reef system may exhibit some functional redundancy at the species level, in terms of feeding on Halimeda spp., but that all 3 species should be considered important for maintaining low biomass of calcified algae on inshore GBR reefs. However, the parrotfishes would not likely be able to replace the siganids and vice versa. All 3 parrotfish species avoided Sargassum sp., and both species of siganids avoided the calcified Halimeda species and Amphiroa sp. Thus, the parrotfishes and siganids display distinct functional separation and exhibit no reciprocal redundancy.

Previous research on macroalgal selection among parrotfishes has concentrated on the genus Sparisoma in the Caribbean, and contrasts markedly with the present study. For example, the seagrass-dwelling species $S$. radians demonstrated avoidance of Halimeda incrassata in field observations (Lobel \& Ogden 1981, Targett et al. 1986). Tank-based preference experiments likewise found the genus Halimeda to be rejec- ted by $S$. viride and $S$. aurofrenatum; Sargassum, Turbinaria, and Padina were preferred (Lewis 1985). However, such Caribbean observations must be interpreted with caution when examining Indo-Pacific patterns. The dominant Caribbean parrotfish genus Sparisoma belongs to a distinct lineage (formerly Sparisomatinae) that feeds in an excavating manner on epilithic algae ( $S$. viride) (Bruggemann et al. 1994) or, more often, in a browsing manner on macroalgae and seagrasses (Randall 1967, Bellwood 1994, Streelman et al. 2002, Westneat et al. 2005). Species in this lineage are relatively rare on Indo-Pacific coral reefs (6 of ca. 71 species; Bellwood 1994). The 3 parrotfishes investigated in the present study are in a separate lineage (formerly the Scarinae). In terms of feeding modes, Chlorurus microrhinos is an excavator, and Hipposcarus longiceps and Scarus rivulatus are both scrapers of the reef substratum (Bellwood \& Choat 1990). Although all 3 species are primarily regarded as grazers of the epilithic algal matrix (Bellwood \& Choat 1990, Bellwood 1994, Wilson et al. 2003, Choat et al. 2004, Fox \& Bellwood 2007), all have previously been reported to feed on macroalgae under experimental conditions (Bellwood et al. 2006, Mantyka \& Bellwood 2007). Thus, the main similarity between Caribbean species and the Indo-Pacific parrotfishes examined in the present study, at this location, is that in both systems, parrotfishes exhibit significant selection, although they may vary considerably in their individual feeding modes.

Most pomacanthids are benthic omnivores that feed on a variety of sponges, tunicates, ascidians, soft corals, and foliose calcareous or turf algae (Allen et al. 1998), and have therefore not been considered to be significant herbivores. In keeping with this omnivorous diet, the pomacanthid Pomacanthus sexstriatus displayed limited selectivity.

The observed differences in feeding selectivity in the present study may reflect functional capabilities in different fish families. Herbivorous parrotfishes including Chlorurus microrhinos, Scarus rivulatus, and Hipposcarus longiceps possess several attributes that facilitate the consumption of heavily calcified food. The specialized teeth, fused dental plates, pharyngeal mill, powerful jaw structure, and lack of an acidic stomach enable species in this family to ingest a diet high in carbonates (Bellwood \& Choat 1990, Bellwood et al. 2003, Choat et al. 2004). Thus, the selectivity of Halimeda by these species of parrotfishes may simply be a reflection of their ability to exploit a readily available food source that is highly defended both morphologically and chemically (Littler et al. 1983, Lewis 1985, Hay \& Fenical 1988). The calcification in Halimeda species may be successful in deterring herbivory by siganids, which have smaller, weaker jaw structures 
and acidic stomachs. Similar results have been reported by Lewis (1985), who found that lightly calcified algae and those with tough, leathery thalli were susceptible to grazing by sparisomatine parrotfishes, but were avoided by surgeonfishes (which have more delicate jaws). In contrast, it is interesting to note that the parrotfishes in our study avoided the red macroalga Galaxaura sp. Although parrotfishes appear to be physically capable of consuming this robust and lightly calcified alga, no consumption was observed. Galaxaura sp. is not known to possess potent anti-herbivore chemicals, but it still appears to be able to deter parrotfish feeding (possibly due to tougher thalli or limited nutritional content rather than calcified tissues).

The differences in selectivity observed here are not solely due to fish morphology. For example, the siganids (Siganus doliatus and S. canaliculatus), the smallest of the 6 fish species examined, selectively ate a tough, non-calcified macroalgal species, Sargassum sp. Furthermore, $S$. doliatus and $S$. canaliculatus appear to share a typical siganid jaw morphology and possess thin-walled, highly acidic stomachs, but $S$. canaliculatus selected different macroalgal species (Sargassum sp. and Padina sp.) compared to S. doliatus (Hypnea sp., Laurencia sp. 2, and Sargassum sp.). Selectivity is not a simple process, and it is possible that ecologically similar species of herbivorous reef fishes have different physiological responses to structural components and algal secondary metabolites (Paul et al. 1990, Meyer et al. 1994). Digestive physiology of herbivorous fishes can vary among species in terms of stomach $\mathrm{pH}$, resident intestinal protozoans (and other microbes), and gut length (Meyer et al. 1994). These characteristics can also vary in an individual species over relatively short periods of time (Meyer et al. 1994).

While gut content analyses have provided valuable information on the relative importance of dietary components and feeding patterns in herbivorous reef fishes (Randall 1967, Wilson et al. 2003, Choat et al. 2004), food selection studies provide a different perspective. Gut content analysis reflects selection in the context of availability. For example, in our study, Sargassum sp. was highly selected by the siganids. However, Sargassum sp. would probably not be abundant in siganid gut contents on a regular basis, as it is not readily available on the reef crest. Thus, gut content analyses may reflect processes that maintain algal distributions in a healthy reef ecosystem (realized niche) rather than processes that can establish patterns (potential niche) or the capacity of a system to cope with change (resilience) such as increasing macroalgae.

Our findings also emphasize the need to consider the criteria for describing functional groups. Although par- rotfishes and siganids are all nominally grazers of the epilithic algal matrix, when conditions change and macroalgae are available (as simulated in this experiment), new potential functional groups are revealed. Under these conditions, parrotfishes are calcified algal browsers and the siganids are highly selective macroalgal browsers. Thus, the functional role of a species is highly context dependent; the role of a species under 'normal' and 'disturbed' conditions may be profoundly different. These 'disturbed' conditions may be experimentally induced, as in this study, but increasingly, human impacts, natural disturbance, and global climate change are modifying the benthic community composition of coral reefs (Hughes et al. 2003, Bellwood et al. 2004), with increased macroalgae being a common characteristic of disturbed reef ecosystems (Mumby et al. 2006, Hughes et al. 2007). In some respects, most of the species in our study represent sleeping functional groups sensu Bellwood et al. (2006) in that their abilities may not be fully exposed until conditions change. This ability to switch functional attributes, and groupings, may be essential for underpinning coral reef resilience in the face of global climate change.

Acknowledgements. We thank the Orpheus Island Research Station staff, T. Sunderland, and M. Pringle for field assistance; A. Hoey for assistance with algal identification; and R. Bonaldo, A. Hoey, N. Paul, G. Russ, S. Wismer, and 3 anonymous reviewers for insightful discussions and/or helpful comments. Financial support was provided by the Australian Research Council (D.R.B.).

\section{LITERATURE CITED}

Allen GR, Steene R, Allen M (1998) A guide to angelfishes and butterflyfishes. Odyssey Publishing, Perth

Bellwood DR (1994) A phylogenetic study of the parrotfishes, Family Scaridae (Pisces: Labroidei), with a revision of genera. Rec Aust Mus Suppl 20:1-86

Bellwood DR, Choat JH (1990) A functional analysis of grazing in parrotfishes (family Scaridae): the ecological implications. Environ Biol Fishes 28:189-214

Bellwood DR, Hoey AS, Choat JH (2003) Limited functional redundancy in high diversity systems: resilience and ecosystem function on coral reefs. Ecol Lett 6:281-285

Bellwood DR, Hughes TP, Folke C, Nystrom M (2004) Confronting the coral reef crisis. Nature 429:827-833

Bellwood DR, Hughes TP, Hoey AS (2006) Sleeping functional group drives coral reef recovery. Curr Biol 16: 2434-2439

Bruggemann JH, Van Oppen MJH, Breeman AM (1994) Foraging by the spotlight parrotfish Sparisoma viride I. Food selection in different, socially determined habitats. Mar Ecol Prog Ser 106:41-55

Ceccarelli DM, Hughes TP, McCook LJ (2006) Impacts of simulated overfishing on the territoriality of coral reef damselfish. Mar Ecol Prog Ser 309:255-262

Choat JH, Robbins WD, Clements KD (2004) The trophic status of herbivorous fishes on coral reefs. II. Food processing modes and trophodynamics. Mar Biol 145:445-454 
Clements KD, Choat JH (1997) Comparison of herbivory in the closely-related marine fish genera Girella and Kyphosus. Mar Biol 127:579-586

Conover WJ (1999) Practical nonparametric statistics. Wiley, New York

Duffy JE, Paul VJ (1992) Prey nutritional quality and the effectiveness of chemical defenses against tropical reef fishes. Oecologia 90:333-339

Fox RJ, Bellwood DR (2007) Quantifying herbivory across a coral reef depth gradient. Mar Ecol Prog Ser 339:49-59

Hay ME, Fenical W (1988) Marine plant-herbivore interactions: the ecology of chemical defense. Annu Rev Ecol Syst 19:111-145

Hughes TP, Baird AH, Bellwood DR, Card M and 13 others (2003) Climate change, human impacts, and the resilience of coral reefs. Science 301:929-933

Hughes TP, Rodrigues MJ, Bellwood DR, Ceccarelli D and 6 others (2007) Phase shifts, herbivory, and the resilience of coral reefs to climate change. Curr Biol 17:360-365

Lewis SM (1985) Herbivory on coral reefs: algal susceptibility to herbivorous fishes. Oecologia 65:370-375

Littler MM, Taylor PR, Littler DS (1983) Algal resistance to herbivory on a Caribbean barrier reef. Coral Reefs 2: $111-118$

Lobel PS, Ogden JC (1981) Foraging by the herbivorous parrotfish Sparisoma radians. Mar Biol 64:173-183

Manly BFJ, McDonald LL, Thomas DL, McDonald TL, Erickson WP (2002) Resource selection by animals, statistical design and analysis for field studies. Kluwer Academic Publishers, Dordrecht

Mantyka CS, Bellwood DR (2007) Direct evaluation of macroalgal removal by herbivorous coral reef fishes. Coral Reefs 26:435-442

Meyer KD, Paul VJ, Sanger HR, Nelson SG (1994) Effects of seaweed extracts and secondary metabolites on feeding by the herbivorous surgeonfish Naso lituratus. Coral Reefs 13:105-112

Mumby PJ, Dahlgren CP, Harborne AR, Kappel CV and 10 others (2006) Fishing, trophic cascades, and the process of grazing on coral reefs. Science 311:98-101

Ojeda FP, Muñoz AA (1999) Feeding selectivity of the herbivorous fish Scartichthys viridis: effects on macroalgal community structure in a temperate rocky intertidal coastal zone. Mar Ecol Prog Ser 184:219-229

Paul VJ, Hay ME (1986) Seaweed susceptibility to herbivory: chemical and morphological correlates. Mar Ecol Prog Ser 33:255-264

Editorial responsibility: Otto Kinne (Editor-in-Chief), Oldendorf/Luhe, Germany
Paul VJ, Nelson SG, Sanger HR (1990) Feeding preferences of adult and juvenile rabbitfish Siganus argenteus in relation to chemical defenses of tropical seaweeds. Mar Ecol Prog Ser 60:23-34

Pillans RD, Franklin CE, Tibbetts IR (2004) Food choice in Siganus fuscescens: influence of macrophyte nutrient content and availability. J Fish Biol 64:297-309

Purcell SW, Bellwood DR (1993) A functional analysis of food procurement in 2 surgeonfish species, Acanthurus nigrofuscus and Ctenochaetus striatus (Acanthuridae). Environ Biol Fishes 37:139-159

Randall JE (1967) Food habits of reef fishes of the West Indies. Stud Trop Oceanogr 5:665-847

Raubenheimer D, Zemke-White WL, Phillips RJ, Clements KD (2005) Algal macronutrients and food selection by the omnivorous marine fish Girella tricuspidata. Ecology 86: $2601-2610$

Steneck R (2001) Functional groups. In: Levin S (ed) Encyclopedia of biodiversity, Vol. 3. Academic Press, Princeton, NJ, p 121-139

Streelman JT, Alfaro M, Westneat MW, Bellwood DR, Karl SA (2002) Evolutionary history of the parrotfishes: biogeography, ecomorphology, and comparative diversity. Evolution 56:961-971

Targett TE, Targett NM (1990) Energetics of food selection by the herbivorous parrotfish Sparisoma radians: roles of assimilation efficiency, gut evacuation rate, and algal secondary metabolites. Mar Ecol Prog Ser 66:13-21

Targett NM, Targett TE, Vrolijk NH, Ogden JC (1986) Effect of macrophyte secondary metabolites on feeding preferences of the herbivorous parrotfish Sparisoma radians. Mar Biol 92:141-148

Tsuda RT, Bryan PG (1973) Food preferences of juvenile Siganus rostratus and S. spinus in Guam. Copeia 1973: 604-609

Von Westernhagen H (1973) The natural food of the rabbitfish Siganus oranim and S. striolata. Mar Biol 22:367-370

Von Westernhagen H (1974) Food preferences in cultured rabbitfishes (Siganidae). Aquaculture 3:109-117

Westneat MW, Alfaro ME, Wainwright PC, Bellwood DR, Grubich JR, Fessler JL, Clements KD, Smith LL (2005) Local phylogenetic divergence and global evolutionary convergence of skull function in reef fishes of the family Labridae. Proc R Soc Lond 272:993-100

Wilson SK, Bellwood DR, Choat JH, Furnas MJ (2003) Detritus in the epilithic algal matrix and its use by coral reef fishes. Oceanogr Mar Biol Annu Rev 41:279-309

Submitted: December 6, 2006; Accepted: May 15, 2007 Proofs received from author(s): December 3, 2007 